\title{
Humanized Mice as an Effective Evaluation System for Peptide Vaccines and Immune Checkpoint Inhibitors
}

\author{
Yoshie Kametani ${ }^{1,2, *}$, Yusuke Ohno ${ }^{1}$, Shino Ohshima ${ }^{1}$, Banri Tsuda ${ }^{3}$, Atsushi Yasuda ${ }^{4}$, \\ Toshiro Seki ${ }^{4}$, Ryoji Ito ${ }^{5}$ (D) and Yutaka Tokuda ${ }^{3}$ \\ 1 Department of Molecular Life Science, Division of Basic Medical Science, Tokai University School of \\ Medicine; 143 Shimokasuya, Isehara-shi, Kanagawa 259-1193, Japan; y-ohno@tsc.u-tokai.ac.jp (Y.O.); \\ shino-w@tokai-u.jp (S.O.) \\ 2 Institute of Advanced Biosciences, Tokai University, 4-1-1 Kitakaname, Hiratsuka-shi, \\ Kanagawa 259-1292, Japan \\ 3 Department of Breast and Endocrine Surgery, Tokai University School of Medicine, 143 Shimokasuya, \\ Isehara-shi, Kanagawa 259-1193, Japan; banri@is.icc.u-tokai.ac.jp (B.T.); tokuda@is.icc.u-tokai.ac.jp (Y.T.) \\ 4 Department of Internal Medicine, Division of Nephrology, Endocrinology and Metabolism, Tokai University \\ School of Medicine, 143 Shimokasuya, Isehara-shi, Kanagawa 259-1193, Japan; \\ yasuda1633@yahoo.co.jp (A.Y.); tsekimdpdd@tokai-u.jp (T.S.) \\ 5 Central Institute for Experimental Animals, 3-25-12 Tonomachi, Kawasaki-ku, Kawasaki-shi, Kanagawa \\ 210-0821, Japan; rito@ciea.or.jp \\ * Correspondence: y-kametn@is.icc.u-tokai.ac.jp; Tel.: +81-463-93-1121 (ext. 2589)
}

Received: 5 November 2019; Accepted: 12 December 2019; Published: 16 December 2019

\begin{abstract}
Peptide vaccination was developed for the prevention and therapy of acute and chronic infectious diseases and cancer. However, vaccine development is challenging, because the patient immune system requires the appropriate human leukocyte antigen (HLA) recognition with the peptide. Moreover, antigens sometimes induce a low response, even if the peptide is presented by antigen-presenting cells and $\mathrm{T}$ cells recognize it. This is because the patient immunity is dampened or restricted by environmental factors. Even if the immune system responds appropriately, newly-developed immune checkpoint inhibitors (ICIs), which are used to increase the immune response against cancer, make the immune environment more complex. The ICIs may activate $\mathrm{T}$ cells, although the ratio of responsive patients is not high. However, the vaccine may induce some immune adverse effects in the presence of ICIs. Therefore, a system is needed to predict such risks. Humanized mouse systems possessing human immune cells have been developed to examine human immunity in vivo. One of the systems which uses transplanted human peripheral blood mononuclear cells (PBMCs) may become a new diagnosis strategy. Various humanized mouse systems are being developed and will become good tools for the prediction of antibody response and immune adverse effects.
\end{abstract}

Keywords: peptide vaccine; immune checkpoint inhibitor; humanized mouse; cancer antigen; immune suppression

\section{Introduction}

Peptide vaccines are widely accepted as a promising strategy to fight infectious disease and cancer. However, the efficacy of a peptide vaccine depends not only on the antigen presentation through antigen-presenting cells but also on the immune environment of each patient, since the immunity of patients with chronic infectious disease and/or cancers tend to be dampened. Therefore, to achieve 
a more personalized medicine, we need a more detailed diagnosis before treatment. We propose the use of the humanized mouse system established through transplanting human peripheral blood mononuclear cells (PBMCs) from a patient into an immunodeficient mouse, for the evaluation of the response to peptide vaccines and other reagents which influence patient immunity. We also describe the immune condition artificially induced by immune checkpoint inhibitors (ICIs) [1] and the reagents against immune-related adverse events (irAEs), followed by the current state-of-the-art advances of humanized mouse systems and the issues to overcome. Moreover, we will discuss whether it is possible to evaluate the patient immunity by using second-generation humanized mice.

\section{Difficulties in the Development of Peptide Vaccines}

The design of peptide vaccines relies on the potential of peptides to bind to the major histocompatibility complex (MHC) in order to be presented by antigen-presenting cells (APCs), such as dendritic cells (DC) and macrophages. However, the MHC binding affinity is not enough to predict the activation of immunity, because the immune condition is different among different patients. Therefore, the decrease in the immune competence should be evaluated when the vaccine is adopted for patients with cancer and/or affected by a chronic infection. The vaccine is not restricted to be used as an anticancer agent; it also includes the influenza vaccine, to be administered to cancer patients [2-4]. Moreover, if the immune checkpoint inhibitors (ICIs) are used for the purpose of immune activation, the situation becomes more complex. We discuss the factors in detail below.

\subsection{Selection of the Adequate Peptide for Vaccination}

Vaccines are categorized as preventive or therapeutic based on their function and are further classified into virus, peptide, DNA, or DC vaccines, depending on the antigen source. Various types of antigens and adjuvants have been developed and evaluated for vaccination against infectious diseases. The design of the peptide antigen is important for inducing the most effective output with each type of vaccine, as each pathogen has a unique strategy for infection and proliferation. However, for long-lasting memory production, protein/peptide-based antigens are essential because the memory requires the activation of $\mathrm{T}$ cells through antigen-presenting cells, such as DC and macrophages. On the other hand, antigens need to activate B cells by crosslinking B-cell receptors (surface Igs). Therefore, the antigen epitope should be exposed to the hydrophilic surface by protruding into the aqueous solution and, thus, being recognized by B cells in vivo.

For the vaccine components to activate $\mathrm{T}$ cells, the antigens should at least contain a highly immunogenic peptide with more than 8 , and up to 30 , residues which can be further presented by the patient MHC (class I for cytotoxic T-cell activation and class II for antibody production). Moreover, as the peptide sequence mutates easily within the virus, it should be selected to maintain the peptide primary structure. The peptide presentation is predicted for HLA and mouse MHC by using available algorithms [5-7]. However, the prediction is incomplete because more new HLA types have been reported [8-10], and even if a peptide is successfully presented by mouse MHC in an experimental design, it does not imply that the same peptide will be presented on HLA. Therefore, larger peptide antigens are typically used in order to include as many epitopes as possible to be presented by major HLAs.

The evaluation of adjuvants is also very important. The induction of inflammation by the adjuvant is effective for the enhancement of the immune response. However, inflammation induction may pose a risk and result in adverse effects for patients. Therefore, self-adjuvanting techniques have been developed for clinical use [11-14]. Among them, the conjugation of molecules related to the ligands of tool-like receptors (TLR) to target peptides may be a safe and effective vaccine adjuvant. The DNA vaccines now, on translational research, use genes of TLR-related molecules. 


\subsection{Antigens which Enable Activation of the Patient Immune System}

While vaccination is the most effective strategy to prevent acute infectious diseases caused by bacteria and viruses, it is not easy to develop effective vaccines against cancer and chronic infectious diseases. Similarly, to antigens present in pathogenic bacteria and viruses, patients with cancer present tumor-associated antigens (TAA) with high antigenicity and immunogenicity. TAAs are classified into differentiation, tissue-specific, mutated, and overexpressed antigens [15]. The U.S. Food and Drug Administration (FDA) has already approved for clinical use several cancer vaccines based on TAAs $[16,17]$. Hepatitis B virus (HBV) and human papilloma virus (HPV) are examples of TAA-based vaccines [18]. There are also unique classic vaccines like sipuleucel-T, the first therapeutic cancer vaccine approved by the FDA [19]. Moreover, many cancer vaccine candidates are currently under investigation in clinical trials, including nucleic acid-containing liposomes and nanoparticles (DNA vaccines) and gp100 peptide (peptide vaccines) [20-22].

On the other hand, especially for tumor-associated peptide vaccines, even if the antigen presentation is satisfied, it is difficult to activate the patient immune system. In spite of the extensive development of vaccines which may induce an anticancer immune response in patients, this response may vary among patients, making the vaccine not always effective. The immune-reactive tumors are called hot tumors, whereas nonimmune reactive tumors are referred to as cold tumors. Hot tumors are thought to have much more cell mutations compared to cold tumors, suggesting that hot tumors have many more TAAs [23]. Accordingly, the hot tumor, which is immune-reactive for the patient, may become the target of peptide vaccines, whereas, in the case of nonreactive cold tumors, the peptide vaccine might be ineffective. In hot tumors, there are some antigens that are highly expressed because of their overexpression on cancer cells. Human epidermal growth factor receptor 2 (HER2) is an example of a TAA molecule, as HER2 is overexpressed on the tumors of patients with breast cancer, and the specific antibody Herceptin is very effective for suppressing cancer progression. Due to the success of antibody reagents, many other human antitumor IgGs have been developed, and their mechanism of action has been investigated [24]. However, the antitumor effect does not last long enough, and the mechanism underlying this effect has not been fully elucidated.

Another problem in the development of cancer vaccines is the incomplete prediction resulting from the algorithms used. Our immune system rejects self-antigen-reactive clones, which may contain cancer-specific clones. Therefore, many of the predicted peptides cannot induce the desired immune response, even though the peptide leads to an immune response in experimental animals. Even if the peptide functions as an antigen, cancer cells have heterogenous mutations in the tumor mass, and, thus, the reactivity of each cancer cell is predicted to be diverse. Therefore, a complete rejection of the cancer cells within the tumor mass is difficult if simply one TAA is selected as peptide antigen.

\subsection{Immune Suppression in Patients Prevents the Effectiveness of Vaccines}

The most important challenge in the design of a vaccine is the immune suppression caused by the patient. The levels of cytotoxic T-cell activation, antibody production, and productive inflammation are different among patients with cancer. Therefore, we cannot predict the patient immune response, even if the peptide vaccine induces an immune response that is similar to the one produced by a viral infection in a healthy individual.

Therefore, although peptide vaccines have been extensively developed, the effect of the anticancer peptide vaccine is very limited, even if the peptide is presented by class I HLA on the patient DCs and the beneficial effect remains, as reviewed by Wong et al. [25]. One of the reasons for this limited effect is that cancer cells are originally "self", and the immune response is basically suppressed by clonal deletion or regulatory immune cell reactions, even though the peptide-reactive CD8 T cells are often detected in the patient PBMC. Even if mutations occur, most of them are limited to a very small region, and the peptides recognized as "non-self" might be very few or suppressed. This mechanism is present in cold tumors. 
Meanwhile, an autoimmune disease might be induced by the suppression of peripheral tolerance. The neutrophil extracellular traps (NETs) play a role in the development of autoimmunity [26,27]. NETs are networks of extracellular fibers that are primarily composed of DNA from neutrophils, which suppress the movement of pathogens. Neutrophils release granule proteins, together with chromatins, and form an extracellular fibril matrix of NETs. The autoantigens involved in neutrophil granular proteins contain very common proteins, such as actin and histones. The proteins vary with the stimulation, and they occasionally induce an autoimmune response. It is important to understand which condition determines if the immune system will or will not induce an autoimmune disease. Moreover, not only cancers, but also some pathogens, induce tolerance. Actually, immature DCs, which induce only an MHC-TCR signal, may induce anergy to self-reactive and non-self-reactive T cells [28].

\section{Immune Checkpoint Inhibitors and Reagents for Side-Effect Regulation}

Recently, adaptive immune-resistant tumor cells which express the programmed-death-L1 (PD-L1) antigen were reported in melanomas by Abiko et al. [29] and Taube et al. [30]. According to their reports, PD-L1 is largely induced on the local tumor cells by tumor-infiltrating lymphocytes (TILs)-derived IFN- $\gamma$ because IFN- $\gamma$ is the most potent inducer of PD-L1in inflammatory cytokines. Upregulation of PD-L1 by IFN- $\gamma$ has been extensively described in various cell types [31-37]. Similarly, TNF- $\alpha$, another pro-inflammatory cytokine, also upregulates PD-L1 expression via TNF- $\alpha$-NF- $\kappa B$ pathway [38-40]. TNF- $\alpha$ is reported to synergistically act with IFN- $\gamma$ to induce PD-L1 expression at both mRNA and protein levels. IFN- $\gamma$ enhances the resistance of the adaptive immune response by PD-L1 induction in hepatocellular carcinoma cells which upregulate the expression of IFN- $\gamma$ receptors [41]. PD-L1 is expressed not only in all hematopoietic cells but also in many non-hematopoietic cell types, such as endothelial and epithelial cells [42,43]. In contrast, PD-L2 expression is more restricted to professional antigen-presenting cells, such as DCs, B cells, and monocytes/macrophages. Besides PD-1, there are other known interacting partners for PD-L1 and PD-L2. PD-L1 also binds to CD80, whereas PD-L2 uses repulsive guidance molecule (RGM) domain family member $B$ (RGMB) as an alternative binding partner. Both types of interaction also inhibit immune responses $[44,45]$.

\subsection{Patients with Cancer}

Recently, the anticancer effect of various immune checkpoint antibodies was elucidated [46]. The "immune checkpoint antibody" induces the blockage of continuous T-cell activation in the periphery. PD-1 antigen is expressed on the long-lived activated T cells, exhausted T cells, and the follicular helper T cells (Tfh) [47,48]. Normally, PD-L1 is expressed on antigen-presenting cells and germinal center B cells [49,50]. Apoptosis is induced when the PD-1-expressing T cells encounter the PD-L1-expressing APCs [49]. When the PD-1/PD-L1 interaction is inhibited by the anti-PD-1 antibody, $T$ cells survive, and the anticancer effect is prolonged. Other immune checkpoint molecules, such as CTLA-4, PD-1, TIM-3, and LAG-3, have been reported, and the ability of the antibodies against such immune checkpoint molecules is being evaluated as anticancer products [51,52]. The effect is remarkable, but the response is still limited to a fraction of patients with cancer. The effect is ordinary, not long-lasting, and the combination of these inhibitors and other anticancer drugs are under investigation.

Moreover, antibodies are so expensive that, before using them as therapeutic agents, a strategy is needed to distinguish among patients that are responsive to the treatment from those that are not. Many biomarkers have been reported to predict the efficacy of the treatment. However, the heterogeneity of tumor masses and the variety of antibodies available make it difficult to find such predictive biomarkers, and even PD-L1 expression might not be a promising marker. Collectively, many studies have suggested that PD-L1 expression on melanoma cells can represent a biomarker to test for the efficacy of anti-PD1 and related antibodies, such as Nivolumab, Ipilimumab, and Pembrolizumab [53-55], and other immune checkpoint inhibitors; however the PD-L1 expression is not always an effective marker for patients with cancer in other clinical trials [56,57]. For example, 
PD-L1 expression on melanoma cells in pretreatment tumor biopsy samples is reported to correlate with response rate, progression free survival, and overall survival in patients with advanced melanoma treated with anti-PD1 antibodies [55], but these antibodies are also effective for PD-L1-negative patients [57].

While the benefits of assessing PD-L1 expression on melanoma cells to predict the clinical outcomes of ICI.

It is already defined. treatment have been suggested, as above, there are still no common criteria of diagnosis. This fact limits the clinical usefulness of the diagnosis of PD-L1 expression, because the low sensitivity of immunohistochemical (IHC) assays using different antibody clones makes it difficult to establish staining platforms and scoring systems [54,55,57-59]. To avoid misprediction by IHC staining, Conroy et al. assessed the expression of PD-L1, using next-generation RNA sequencing, but the sensitivity of their system resembles that of IHC assay systems and is, in addition, more expensive [58]. Additional assays or completely different assay systems will be needed in the future to diagnose PD-L1 expression of patient cancer tissues, for the prediction of clinical outcomes for the ICI treatment of melanoma [60].

\subsection{Patients with Infectious Diseases}

Viral infections do not always enhance PD-L1 expression, because similar PD-L1 levels are detected in individuals not infected with viruses [61-64]. Increased PD-L1 levels are related to specific viruses, such as the following: Epstein-Barr virus (EBV) [65-68], hepatitis B virus (HBV) [69-71], hepatitis $\mathrm{C}$ virus (HCV) [72-75], human immunodeficiency virus (HIV) [63,76-79], human papilloma virus (HPV) [68,80-83], Merkel cell polyomavirus (MCPyV) [84], bovine leukemia virus (BLV) [85], and Kaposi sarcoma-associated herpes virus (KSHV) [86]. The pathobiological mechanisms by which viruses trigger the expression of PD-L1 have been elucidated. Pathogen-associated molecular patterns (PAMPs) such as lipopolysaccharides (LPS), double-stranded RNA, and non-methylated CpG, from virus, bacteria, and fungi, activate toll-like receptors (TLRs) to induce the immune response and protect the host against the infection. Therefore, the effect of PD-1/PD-L1 blockage by ICI might not be limited to blocking cancer-T-cell interaction. Other hematopoietic lineage cells expressing PD-1 and/or PD-L1 might also be affected. For example, a fraction of plasmablasts and regulatory B (Breg) cells also express PD-L1 $[87,88]$. Therefore, the blockage of the axis may affect the humoral immunity or Breg cells. However, the antigen-specific reaction in such a systemic immunity is difficult to analyze in vivo.

\subsection{Steroid Hormones and ICI Side Effects}

Glucocorticoids are a class of steroid hormones that are powerful immune-suppressants that produce an effect on the systemic immune response. Conditions such as pregnancy and chronic inflammation may induce glucocorticoid secretion. Glucocorticoids [89] secreted by the stimulation of chronic inflammation are widely used as anti-inflammatory drugs. While they induce various signals related to cytokine and Fc receptors that modify metabolism and immune responses, it was recently reported that glucocorticoids impair upstream B-cell-receptor and Toll-like-receptor 7 signaling, reduce transcriptional output from the immunoglobulin loci, and promote significant upregulation of genes encoding the immunomodulatory cytokine IL-10 and the terminal-differentiation factor BLI MP-1 [90]. Expression of $\kappa$ light chain and the two variable regions are especially suppressed. If patients affected with cancer or severe infectious diseases increase their glucocorticoid levels in order to overcome the disease-induced inflammation, or if they are treated with glucocorticoid because of the regulation of anticancer drug-induced side effects, the anticancer Ig expression might be suppressed. If the inflammatory, glucocorticoid-abundant condition continues, the potential for antibody production in the patient may be dampened. Therefore, if the PBMC of patients is examined for the antibody-production response, we may be able to predict if the patient is exposed to such steroid-based immune suppression. Glucocorticoids have also been reported to enhance metastasis in breast cancer [91]; therefore, their effect on patients with cancer needs to be examined in more detail. 
On the other hand, it has been reported that ICI treatments occasionally induce a typical side effect related to pituitary dysfunction. Notably, hypophysitis, a previously very rare disease, has emerged as a distinctive side effect of ipilimumab and occasionally of nivolumab [92]. These side effects are not limited only to the pituitary; they also affect the thyroid, adrenal glands, and other downstream-target organs [93].

\section{Humanized Mouse Models for the Evaluation of the Human Immune Environment}

As we mentioned above, the prediction of the protective immunity development by vaccination is difficult because the immune condition is diverse in each patient, and the appropriate ICIs and induced irAEs may not be predicted. In order to determine the protocol reflecting the immune condition of each patient, the so-called personalized medicine, a humanized mouse system reconstituted with the patient immunity, may be useful [94]. The immunization with vaccines may reveal not only the effect of a specific vaccine, but it may also provide information regarding the patient immune response to mimic the anticancer/pathogen response. The current status of the humanized mouse system involving next generation humanized mice and its limitations is shown in Figure 1 (cellular immunity) and discussed below $[95,96]$.

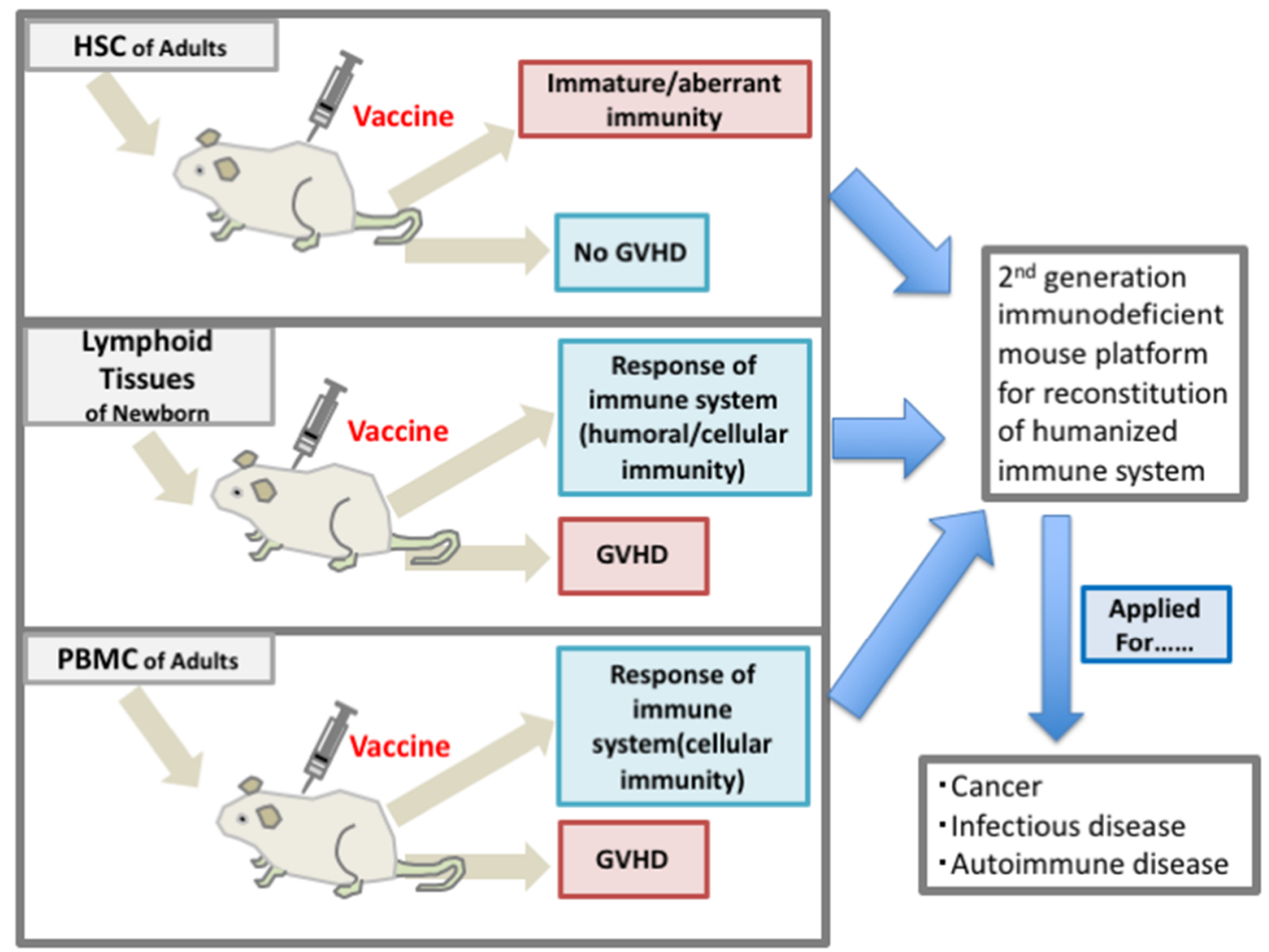

Figure 1. Three strategies for the reconstitution of human immunity in the immunodeficient mouse. The transplanted tissues are HSC, Lymphoid tissues or the fragments of mnewborn, and PBMCs. Many kinds of antigens and pathogens were used for the analysis.

\subsection{Humanized Mice for Reconstitution of the Human Immune System with Hematopoietic Cells}

The humanized mouse system was originally developed to evaluate the multipotency of human HSC s or progenitors. Severely immunodeficient mouse strains, as well as the transplantation techniques, have recently been developed [97-100]. After the discovery of the nonobese diabetic severe combined immunodeficient mouse (NOD-scid) model and its derivatives, transplantation of human hematopoietic stem cells (HSCs) into these mice led to the development of human lymphocytes and myeloid cells which, 
are localized in the primary and secondary lymphoid tissues of the mouse [101-103]. These mouse models have been used to analyze the differentiation of human hematopoietic and leukemic stem cells [104]. On the other hand, because of the success of humanized monoclonal antibody reagents such as trastuzumab and rituximab, completely human-type antibody production has also been attempted, using these mouse models transplanted with various types of human hematopoietic cells [105].

NOD/Shi-scid-IL2R $\gamma^{\text {null }}$ (NOG), developed at the Central Institute for Experimental Animals, and NOD scid gamma (NSG), developed at the Jackson Laboratory, are two representatives of severely immunodeficient mouse strains. Both mouse strains have a deficiency in IL-2rgc [97,106-108]. NOG mice possess a truncated IL-2rgc, and NSG mice have a complete deletion of the gene coding for IL-2rgc; the efficiency of the engraftment and the differentiation efficiency are comparable in the two strains. Both of them enabled the development of human T and B cells from human HSCs in a xenogenic environment. However, most of the human B cells differentiated in the mice expressed CD5, a marker of B1 cells, and the specific IgG antibody is not produced [109-113] (Table 1). We reconstructed human immunity in NOG mice transplanted with HSC and immunized with CH401MAP, a specific HER2 peptide antigen for patients with breast cancer, and keyhole limpet hemocyanin (KLH), or toxic shock syndrome toxin-1 (TSST-1), with Freund's complete adjuvant and measured the specific antibody titer by ELISA. As a result, although antigen-specific IgM and nonspecific IgG were detected in the sera, antigen-specific IgG was not detected in mice (Table 1) [114-116]. These mice did not develop a germinal center, which has a structure composed of T, B, and follicular DCs and plays a crucial role in highly specific crass-switched IgG antibody production. The results indicated that human $\mathrm{T}$ cells and $\mathrm{B}$ cells developed in the mouse environment could not induce cognate interaction, because the $\mathrm{T}$ cells are selected for mouse MHC in the thymus. 
Table 1. Humanized mice with antigen-specific antibody production.

\begin{tabular}{|c|c|c|c|c|c|}
\hline & Mouse Strain. & Transplanted Tissues & Antigen & Isotype & Reference \\
\hline SCID-Hu & SCID & $\begin{array}{l}\text { human fetal liver and thymic } \\
\text { fragments under kidney capsule }\end{array}$ & pneumococcal vaccine & $\operatorname{Ig} G$ & $\begin{array}{c}\text { McCune JM } 1988 \text { [117], } \\
\text { Aaberge IS et al., } 1992 \text { [118] }\end{array}$ \\
\hline \multirow{6}{*}{ Hu-HSC } & NOG & $\mathrm{HSC}(\mathrm{CB} / \mathrm{MPB} / \mathrm{BM})$ i.v. & DNP-KLH/CH401MAP/TSST-1 & $\operatorname{IgM}$ & $\begin{array}{l}\text { Matsumura T et al., } 2003 \text { [109], } \\
\text { Kametani Y et al., } 2006 \text { [114] }\end{array}$ \\
\hline & $\begin{array}{c}\text { NSG; Balb/c-Rag1(-/-) gammac(-/-); } \\
\text { C.B-17-scid/bg }\end{array}$ & $\mathrm{HSC}(\mathrm{CB} / \mathrm{MPB} / \mathrm{HFL})$ i.v. & $\mathrm{KLH} /$ inactivated H5N1 influenza virus & $\operatorname{IgM}, \operatorname{IgG}$ & Lepus CM et al., 2009 [111] \\
\hline & NOG & CD34 + HSC i.v. & OVA & Igs & $\begin{array}{l}\text { Yajima M et al., } 2008 \text { [98], } \\
\text { Watanabe Y et al., } 2009 \text { [112] }\end{array}$ \\
\hline & NSG & human CD34 + HSC i.v. & OVA, HIV & $\operatorname{IgM}, \operatorname{IgG}$ & $\begin{array}{l}\text { Wtanabe S et al., } 2007 \text { [110], } \\
\text { Singh M et al., } 2012 \text { [102] }\end{array}$ \\
\hline & NOG-HLA-DR4/Ab KO & human CD34 + HSC i.v. & OVA & IgM, IgG & Suzuki M et al., 2012 [119] \\
\hline & NSG-HIS-CD4/B & human CD34 + HSC i.v. & $\begin{array}{l}\text { Plasmodium falciparum, } \\
\text { circumsporo-zoite (PFCS) protein }\end{array}$ & $\operatorname{Ig} G$ & Huang J et al., 2015 [120] \\
\hline \multirow{3}{*}{ Hu-PBL } & SCID & human PBMC i.v. & xenograft & IgM, IgG & Williams S et al., 1992 [121] \\
\hline & NOG-IL-4-Tg & human PBMC i.v. & KLH/CH401MAP & $\operatorname{IgG}$ & Kametani Y et al., 2017 [116] \\
\hline & DKO-NOG & human PBMC i.v. & human Liver xenograft, & Igs & Aono S et al. 2018 [122] \\
\hline \multirow{3}{*}{ BLT } & SCID & $\begin{array}{l}\text { human fetal liver and thymic } \\
\text { fragments under kidney capsule } \\
\text { with autologous CD34 + HSC } \\
\text { human fetal liver and thymic }\end{array}$ & & $\operatorname{IgG}$ & $\begin{array}{l}\text { McCune JM et al., } 1988 \text { [123], } \\
\text { Aaberge IS et al., } 1992 \text { [118] }\end{array}$ \\
\hline & NOD-SCID & $\begin{array}{l}\text { fragments under kidney capsule } \\
\text { with autologous CD34 + HSC }\end{array}$ & HIV-1, WNV envelope protein & $\operatorname{IgM}, \operatorname{IgG}$ & Biswas et al., 2011 [113] \\
\hline & NSG & $\begin{array}{l}\text { human fetal liver and thymic } \\
\text { fragments under kidney capsule } \\
\text { with autologous CD34 + HSC }\end{array}$ & $\begin{array}{l}\text { pneumococcal vaccine, Dengue virus } \\
\text { infection, Zika virus, HIV -1 gp120 }\end{array}$ & $\operatorname{IgM}, \operatorname{IgG}, \operatorname{Ig} \mathrm{A}$ & $\begin{array}{c}\text { Jaiswal S et al., } 2015 \text { [124], } \\
\text { Jangalwe S et al., } 2016 \text { [125], } \\
\text { Schmitt K et al., } 2018 \text { [126], } \\
\text { Gawron MA et al., } 2019 \text { [127] }\end{array}$ \\
\hline
\end{tabular}

Representative immune-humanized mouse systems which induced antibody production are shown. The data are based on PubMed, published from 1988 to 2019. 
After the first trial with NOG and NSG mouse models, the animals with mouse MHC knockout and HLA transgenic antigen were developed to induce cognate interaction of T cells and B cells. Among them, HLA class I transgenic mice evoked antigen-specific cytotoxic T-cell response against HSV virion protein peptide [128] or WT1 peptide [129]. The success of the reconstitution of human cellular immune response was followed by an adoptive transfer therapy model using the humanized-mouse system [130]. Consequently, the established patient-derived xenograft (PDX) system, which transplants a patient's cancer tissues (minimal standard was reported by Meehan et al. [131]), combined with a patient's T cells, is widely accepted. The detail was intensively reviewed by other researchers [132-134].

On the other hand, the response of HLA class II transgenic mice did not completely mimic the human humoral immunity $[119,120,125]$. Moreover, mice need to be transplanted with the same HLA-bearing human HSCs, which restrict the samples to be examined. Among them, Ashizawa et al. reported that class I and class II MHC KO NOG mice (NOG dKO) transplanted with human PBMC and tumor cell lines showed higher anticancer effects after PD-1 antibody treatment [135]. In these mouse strains, transplanted tumor cells and immune cells can be engrafted, and the anticancer effect of human immune cells can be observed (reviewed by Chen et al. [95]). The mouse system had an advantage, which is that the restriction of HLA type could be avoided by using PBMC, which contain the same patient's $T$ cells and antigen-presenting cells. However, they did not detect anticancer antibody production in this study.

Currently, various transgenic mouse strains expressing human cytokines and surface antigens, along with more severely immunodeficient mouse strains, are being developed to transplant human hematopoietic cells (HSC or PBMC). The category of newly-established mouse system includes myeloid cell development, cancer immunotherapy model, allergy model, and graft-versus-host disease (GVHD) model.

Another humanized mouse model, called BLT mice, has been reported. In this mouse model, immunodeficient mice are co-transplanted with human fetal liver and thymus tissues, along with autologous CD34 + HSCs. This mouse system is a modification of the SCID-Hu mice developed by MacCune $[113,117,123]$. In these mice, antigen-specific antibody production was partially achieved, and experiments on infection with bacteria or viruses were conducted [118]. Severely immunodeficient NSG mice are used to establish NSG-BLT mice [136]. A modified NSG mice, in which Human SCF, GM-CSF, and IL-3 genes were transduced, was used to establish an improved BLT mouse strain. Based on the NSG mouse strain, human HSCs, fetal liver, and fetal thymus were transplanted, and mice were inoculated with dengue and/or Zika virus. As a result, these mice induced a higher immune response than that of conventional NSG mice, although graft-versus-host disease (GVHD) could not be avoided $[124,126,127]$. However, because of a serious ethical problem, Japanese researchers are unable to establish the BLT mouse system. The BLT model system succeeded in the induction of the cytotoxic immune response with no mature humoral immunity, maybe because the cytotoxicity is too high to maintain the antibody production (discussed in [94]).

Collectively, many of the strains support the differentiation of various hematopoietic cell lineages from human HSCs. Moreover, PBMC engrafts in the mice and can reconstitute human cellular immunity. However, human humoral immune response in a mouse model still needs further improvement: it is impossible, so far, to reconstruct the immune condition involving humoral immunity of various patients.

\subsection{Humanized Mouse System to Evaluate Antigen-Specific Antibody Production}

It is difficult to completely develop humoral immunity in humanized mice because of the reasons exposed above. While $\mathrm{T}$ cell-B cell interaction needs cognate interaction, humans have a large variety of HLA types, and it is difficult to cover all the HLA types present in a patient blood. Immunodeficient mice transplanted with PBMCs are promising tools to evaluate human immune responses to vaccines, compared to the HSC-transplanting mouse system. However, these mice usually develop severe GVHD [137]. With GVHD, mice develop a large amount of activated T cells, while B cells are decreased in parallel, and there is no humoral immune response. Therefore, it is 
difficult to evaluate the production of antigen-specific IgG production after antigen immunization in those mice. To evaluate antigen-specific IgG responses in PBMC-transplanted immunodeficient mice, we developed a novel NOD/Shi-scid-IL2rgnull (NOG) mouse strain that systemically expresses the human IL-4 gene (NOG-hIL-4-Tg) [116]. After human PBMC transplantation, GVHD symptoms were significantly suppressed in the Tg NOG, as compared to conventional NOG mice. In the kinetic analyses of human leukocytes, long-term engraftment of human $\mathrm{T}$ cells has been observed in peripheral blood of NOG-hIL-4-Tg, and then CD4+ T cells dominantly proliferated rather than CD8+ T cells. Furthermore, these CD4+ T cells produced large amounts of IL-4 but suppressed IFN-g expression, resulting in long-term suppression of GVHD. Most of the human B cells detected in the transplanted mice showed a plasmablast phenotype. Vaccination with HER2 multiple antigen peptide (CH401MAP) or keyhole limpet hemocyanin (KLH) successfully induced antigen-specific IgG production in PBMC-transplanted NOG-hIL-4-Tg. The HLA haplotype of donor PBMC might not be relevant to the ability of an antibody secretion after immunization. The reason why NOG-hIL-4-Tg retain B cells and succeeded in the specific antibody production was examined, and we found that the engrafted human lymphocytes decreased glucocorticoid receptor expression, which dampens the humoral immunity [138].

This evidence suggests that the PBMC-transplanted NOG-hIL-4-Tg mouse system is an effective tool to evaluate the production of antigen-specific IgG antibodies, following vaccination in individual cancer patients [116]. The mouse system can be used for the evaluation of the effect of ICIs on antibody production in the presence of human PBMCs, as well.

Of course, the vaccination is not limited to cancer vaccines. As plasmablasts are efficiently developed, the evaluation of vaccines against highly deleterious pathogens, such as Ebola virus, may become possible. Moreover, the donors recovered from such serious infectious disease may keep their memory B cells against the pathogen. Therefore, the transplantation of the PBMCs may develop plasma cells that secrete effective antipathogen antibodies. If we establish the technology for monoclonal antibody preparation, we may obtain the monoclonal antibody reagents for the treatment of such deleterious infectious diseases.

The humanized mouse systems discussed are summarized in Table 1.

\section{Future Perspectives}

Because the efficacy of the peptide vaccine is influenced by the immune-cell environment and the patient's body fluid content, we need to evaluate vaccines by constructing patient-mimicking conditions. If we can establish patient-PBMC-based check systems using the humanized mouse model for vaccination and additional reagents, we may check the vaccination efficiency, ICI, and IAEs at the same time. If those goals are achieved, they may enable a promising personalized medicine, such as in the case of the use of the mixed lymphocyte reaction for blood-type examination before transplantation. Therefore, it is urgent to develop humanized mice which reconstitute not only human immune cells but the environment of the actual patient. By using the PBMC-based humanized mouse system, various vaccines can be evaluated for their efficacy. We need to improve the humanized mouse system to fine-tune the peptide design for vaccine development.

Author Contributions: Conceptualization, Y.K., T.S., Y.T. and R.I.; analysis, Y.O., S.O., B.T., A.Y. and Y.K. drafted the work.

Funding: The NOG researchs were supported by Japan Society for the Promotion of Science by a Grant-in-Aid for Scientific Research (ITO) (S) [grant number 22220007] to MI; a Grant-in-Aid for Scientific Research (Kametani) (B) [grant number 17H03571] to YK; a Tokai University Grant-in-Aid to YK (2013-2014); and the MEXT-Supported Program for the Strategic Research Foundation at Private Universities (2012-2016).

Acknowledgments: We thank Yumiko Nakagawa for her excellent animal care skills. We thank the members of the Teaching and Research Support Center in the Tokai University School of Medicine for their technical skills.

Conflicts of Interest: We have no conflicts of interest. 


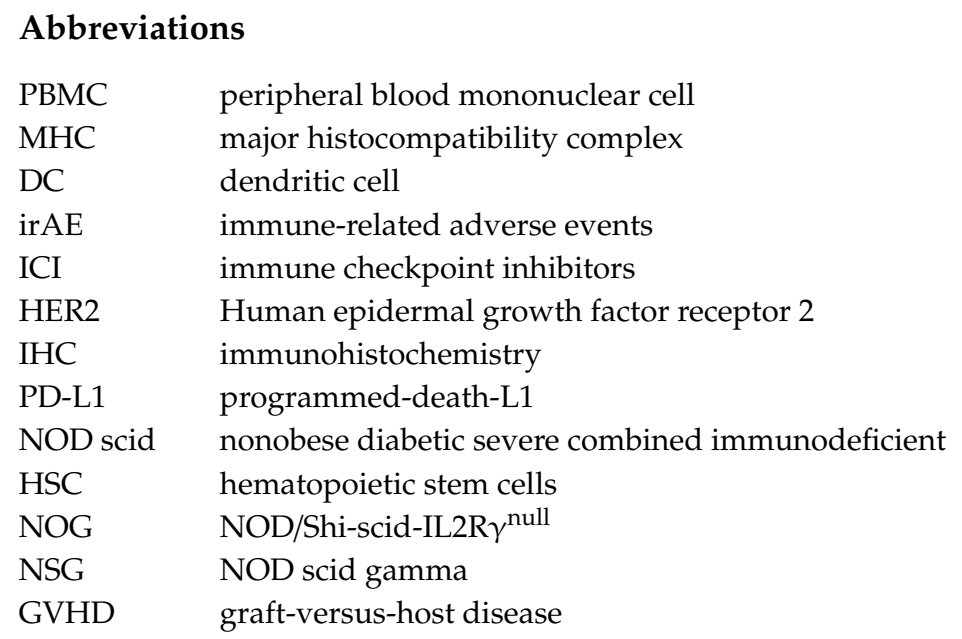

\section{References}

1. Marshall, H.; Djamgoz, M. Immuno-Oncology: Emerging Targets and Combination Therapies. Front. Oncol. 2018, 8, 315. [CrossRef] [PubMed]

2. Wilkinson, K.; Wei, Y.; Szwajcer, A.; Rabbani, R.; Zarychanski, R.; Abou-Setta, A.; Mahmud, S. Efficacy and safety of high-dose influenza vaccine in elderly adults: A systematic review and meta-analysis. Vaccine 2017, 35, 2775-2780. [CrossRef] [PubMed]

3. Nakashima, K.; Aoshima, M.; Ohfuji, S.; Suzuki, K.; Katsurada, M.; Katsurada, N.; Misawa, M.; Otsuka, Y.; Kondo, K.; Hirota, Y. Immunogenicity of trivalent influenza vaccine in patients with lung cancer undergoing anticancer chemotherapy. Hum. Vaccin Immunother. 2017, 13, 543-550. [CrossRef] [PubMed]

4. Waqar, S.; Boehmer, L.; Morgensztern, D.; Wang-Gillam, A.; Sorscher, S.; Lawrence, S.; Gao, F.; Guebert, K.; Williams, K.; Govindan, R. Immunogenicity of Influenza Vaccination in Patients With Cancer. Am. J. Clin. Oncol. 2018, 41, 248-253. [CrossRef]

5. Andreatta, M.; Karosiene, E.; Rasmussen, M.; Stryhn, A.; Buus, S.; Nielsen, M. Accurate pan-specific prediction of peptide-MHC class II binding affinity with improved binding core identification. Immunogenetics 2015, 67, 641-650. [CrossRef]

6. Andreatta, M.; Nielsen, M. Gapped sequence alignment using artificial neural networks: Application to the MHC class I system. Bioinformatics 2016, 32, 511-517. [CrossRef]

7. Rasmussen, M.; Fenoy, E.; Harndahl, M.; Kristensen, A.; Nielsen, I.; Nielsen, M.; Buus, S. Pan-Specific Prediction of Peptide-MHC Class I Complex Stability, a Correlate of T Cell Immunogenicity. J. Immunol. 2016, 197, 1517-1524. [CrossRef]

8. Wang, J.; Ji, X.; Ou, G.; Su, P.; Liu, Z. LA-B*46:40:02, a novel HLA-B*46 allele identified in a Chinese individual by sequence-based typing. Hla 2016, 87, 462-464. [CrossRef]

9. Li, J.; Zhang, X.; Lin, F.; Zhang, K.; Li, X.F. Identification of the novel HLA allele, HLA-B*40:06:07, by sequence-based typing. Hla 2018, 92, 326-327. [CrossRef]

10. Proust, B.; Masson, D.; Proust, B.; Baudron, M.; Dehaut, F. Identification of a novel HLA allele, HLA-B*08:163, in a platelet donor. Hla 2016, 88, 263-264. [CrossRef]

11. Moyle, P.; Toth, I. Self-adjuvanting lipopeptide vaccines. Curr. Med. Chem. 2008, 15, 506-516. [CrossRef] [PubMed]

12. Pasquevich, K.; García Samartino, C.; Coria, L.; Estein, S.; Zwerdling, A.; Ibañez, A.; Barrionuevo, P.; Oliveira, F.; Carvalho, N.; Borkowski, J.; et al. The protein moiety of Brucella abortus outer membrane protein 16 is a new bacterial pathogen-associated molecular pattern that activates dendritic cells in vivo, induces a Th1 immune response, and is a promising self-adjuvanting vaccine against systemic and oral acquired brucellosis. J. Immunol. 2010, 184, 5200-5212.

13. Shen, K.; Chang, L.; Leng, C.; Liu, S. Self-adjuvanting lipoimmunogens for therapeutic HPV vaccine development: Potential clinical impact. Expert Rev. Vaccines 2015, 14, 383-394. [CrossRef] [PubMed] 
14. Zeng, B.; Middelberg, A.; Gemiarto, A.; MacDonald, K.; Baxter, A.; Talekar, M.; Moi, D.; Tullett, K.; Caminschi, I.; Lahoud, M.; et al. Self-adjuvanting nanoemulsion targeting dendritic cell receptor Clec9A enables antigen-specific immunotherapy. J. Clin. Investig. 2018, 128, 1971-1984. [CrossRef] [PubMed]

15. Wang, R. Human tumor antigens: Implications for cancer vaccine development. J. Mol. Med. 1999, 77, 640-655. [CrossRef]

16. Bezu, L.; Kepp, O.; Cerrato, G.; Pol, J.; Fucikova, J.; Spisek, R.; Zitvogel, L.; Kroemer, G.; Galluzzi, L. Trial watch: Peptide-based vaccines in anticancer therapy. Oncoimmunology 2018, 7, e1511506. [CrossRef]

17. Wang, Y.; Yang, L.; Zuo, J. Recent developments in antivirals against hepatitis B virus. Virus Res. 2016, 213, 205-213. [CrossRef]

18. Kanduc, D.; Shoenfeld, Y. From HBV to HPV: Designing vaccines for extensive and intensive vaccination campaigns worldwide. Autoimmun. Rev. 2016, 15, 1054-1061. [CrossRef]

19. Cheever, M.; Higano, C. PROVENGE (Sipuleucel-T) in prostate cancer: The first FDA-approved therapeutic cancer vaccine. Clin. Cancer Res. 2011, 17, 3520-3526. [CrossRef]

20. Guevara, M.; Persano, S.; Persano, F. Lipid-Based Vectors for Therapeutic mRNA-Based Anti-Cancer Vaccines. Curr. Pharm. Des. 2019, 25, 1443-1454. [CrossRef]

21. Park, S.; Kim, D.; Wu, G.; Jung, H.; Park, J.; Kwon, H.; Lee, Y. A peptide-CpG-DNA-liposome complex vaccine targeting TM4SF5 suppresses growth of pancreatic cancer in a mouse allograft model. Onco Targets Ther. 2018, 11, 8655-8672. [CrossRef] [PubMed]

22. Schwartzentruber, D.; Lawson, D.; Richards, J.; Conry, R.; Miller, D.; Treisman, J.; Gailani, F.; Riley, L.; Conlon, K.; Pockaj, B.; et al. gp100 peptide vaccine and interleukin-2 in patients with advanced melanoma. N. Engl. J. Med. 2011, 364, 2119-2127. [CrossRef] [PubMed]

23. Wargo, J.; Reddy, S.; Reuben, A.; Sharma, P. Monitoring immune responses in the tumor microenvironment. Curr. Opin. Immunol. 2016, 41, 23-31. [CrossRef] [PubMed]

24. Desjarlais, J.; Lazar, G.; Zhukovsky, E.; Chu, S. Optimizing engagement of the immune system by anti-tumor antibodies: An engineer's perspective. Drug Discov. Today 2007, 12, 898-910. [CrossRef] [PubMed]

25. Wong, K.; Li, W.; Mooney, D.; Dranoff, G. Advances in Therapeutic Cancer Vaccines. Adv. Immunol. 2016, 130, 191-249.

26. Papayannopoulos, V. Neutrophil extracellular traps in immunity and disease. Nat. Rev. Immunol. 2018, 18, 134-147. [CrossRef]

27. Skopelja-Gardner, S.; Jones, J.; Rigby, W. "NETtling” the host: Breaking of tolerance in chronic inflammation and chronic infection. J. Autoimmun. 2018, 88, 1-10. [CrossRef]

28. Steinman, R.; Nussenzweig, M. Avoiding horror autotoxicus: The importance of dendritic cells in peripheral T cell tolerance. Proc. Natl. Acad. Sci. USA 2002, 99, 351-358. [CrossRef]

29. Abiko, K.; Matsumura, N.; Hamanishi, J.; Horikawa, N.; Murakami, R.; Yamaguchi, K.; Yoshioka, Y.; Baba, T.; Konishi, I.; Mandai, M. IFN- $\gamma$ from lymphocytes induces PD-L1 expression and promotes progression of ovarian cancer. Br. J. Cancer 2015, 112, 150-159. [CrossRef]

30. Taube, J.; Anders, R.; Young, G.; Xu, H.; Sharma, R.; McMiller, T.; Chen, S.; Klein, A.; Pardoll, D.; Topalian, S.; et al. Colocalization of inflammatory response with B7-h1 expression in human melanocytic lesions supports an adaptive resistance mechanism of immune escape. Sci. Transl. Med. 2012, 4, 127ra37. [CrossRef]

31. Mazanet, M.; Hughes, C. B7-H1 is expressed by human endothelial cells and suppresses T cell cytokine synthesis. J. Immunol. 2002, 169, 3581-3588. [CrossRef] [PubMed]

32. Brown, J.; Dorfman, D.; Ma, F.; Sullivan, E.; Munoz, O.; Wood, C.; Greenfield, E.; Freeman, G. Blockade of programmed death-1 ligands on dendritic cells enhances T cell activation and cytokine production. J. Immunol. 2003, 170, 1257-1266. [CrossRef] [PubMed]

33. Wintterle, S.; Schreiner, B.; Mitsdoerffer, M.; Schneider, D.; Chen, L.; Meyermann, R.; Weller, M.; Wiendl, H. Expression of the B7-related molecule B7-H1 by glioma cells: A potential mechanism of immune paralysis. Cancer Res. 2003, 63, 7462-7467. [PubMed]

34. Schoop, R.; Wahl, P.; Le Hir, M.; Heemann, U.; Wang, M.; Wüthrich, R. Suppressed T-cell activation by IFN-gamma-induced expression of PD-L1 on renal tubular epithelial cells. Nephrol. Dial. Transplant. 2004, 19, 2713-2720. [CrossRef] [PubMed]

35. de Kleijn, S.; Langereis, J.; Leentjens, J.; Kox, M.; Netea, M.; Koenderman, L.; Ferwerda, G.; Pickkers, P.; Hermans, P. IFN- $\gamma$-stimulated neutrophils suppress lymphocyte proliferation through expression of PD-L1. PLoS ONE 2013, 8, e72249. [CrossRef] 
36. Garcia-Diaz, A.; Shin, D.; Moreno, B.; Saco, J.; Escuin-Ordinas, H.; Rodriguez, G.; Zaretsky, J.; Sun, L.; Hugo, W.; Wang, X.; et al. Interferon Receptor Signaling Pathways Regulating PD-L1 and PD-L2 Expression. Cell Rep. 2017, 19, 1189-1201. [CrossRef]

37. Lim, S.; Li, C.; Xia, W.; Cha, J.; Chan, L.; Wu, Y.; Chang, S.; Lin, W.; Hsu, J.; Hsu, Y.; et al. Deubiquitination and Stabilization of PD-L1 by CSN5. Cancer Cell 2016, 30, 925-939. [CrossRef]

38. Grinberg-Bleyer, Y.; Ghosh, S. A Novel Link between Inflammation and Cancer. Cancer Cell 2016, 30, 829-830. [CrossRef]

39. Kondo, A.; Yamashita, T.; Tamura, H.; Zhao, W.; Tsuji, T.; Shimizu, M.; Shinya, E.; Takahashi, H.; Tamada, K.; Chen, L.; et al. Interferon-gamma and tumor necrosis factor-alpha induce an immunoinhibitory molecule, B7-H1, via nuclear factor-kappaB activation in blasts in myelodysplastic syndromes. Blood 2010, 116, 1124-1131. [CrossRef]

40. Quandt, D.; Jasinski-Bergner, S.; Müller, U.; Schulze, B.; Seliger, B. Synergistic effects of IL-4 and TNF $\alpha$ on the induction of B7-H1 in renal cell carcinoma cells inhibiting allogeneic T cell proliferation. J. Transl. Med. 2014, 12, 151. [CrossRef]

41. Li, N.; Wang, J.; Zhang, N.; Zhuang, M.; Zong, Z.; Zou, J.; Li, G.; Wang, X.; Zhou, H.; Zhang, L.; et al. Cross-talk between TNF- $\alpha$ and IFN- $\gamma$ signaling in induction of B7-H1 expression in hepatocellular carcinoma cells. Cancer Immunol. Immunother. 2018, 67, 271-283. [CrossRef] [PubMed]

42. Weyand, C.; Berry, G.; Goronzy, J. The immunoinhibitory PD-1/PD-L1 pathway in inflammatory blood vessel disease. J. Leukoc. Biol. 2018, 103, 565-575. [CrossRef] [PubMed]

43. Kythreotou, A.; Siddique, A.; Mauri, F.; Bower, M.; Pinato, D. PD-L1. J. Clin. Pathol. 2018, 71, $189-194$. [CrossRef]

44. Butte, M.; Peña-Cruz, V.; Kim, M.; Freeman, G.; Sharpe, A. Interaction of human PD-L1 and B7-1. Mol. Immunol. 2008, 45, 3567-3572. [CrossRef] [PubMed]

45. Xiao, Y.; Yu, S.; Zhu, B.; Bedoret, D.; Bu, X.; Francisco, L.; Hua, P.; Duke-Cohan, J.; Umetsu, D.; Sharpe, A.; et al. RGMb is a novel binding partner for PD-L2 and its engagement with PD-L2 promotes respiratory tolerance. J. Exp. Med. 2014, 211, 943-959. [CrossRef]

46. Balar, A.; Weber, J. PD-1 and PD-L1 antibodies in cancer: Current status and future directions. Cancer Immunol. Immunother. 2017, 66, 551-564. [CrossRef]

47. Agata, Y.; Kawasaki, A.; Nishimura, H.; Ishida, Y.; Tsubata, T.; Yagita, H.; Honjo, T. Expression of the PD-1 antigen on the surface of stimulated mouse $\mathrm{T}$ and B lymphocytes. Int. Immunol. 1996, 8, 765-772. [CrossRef]

48. Haynes, N.; Allen, C.; Lesley, R.; Ansel, K.; Killeen, N.; Cyster, J. Role of CXCR5 and CCR7 in follicular Th cell positioning and appearance of a programmed cell death gene-1high germinal center-associated subpopulation. J. Immunol. 2007, 179, 5099-5108. [CrossRef]

49. Freeman, G.; Long, A.; Iwai, Y.; Bourque, K.; Chernova, T.; Nishimura, H.; Fitz, L.; Malenkovich, N.; Okazaki, T.; Byrne, M.; et al. Engagement of the PD-1 immunoinhibitory receptor by a novel B7 family member leads to negative regulation of lymphocyte activation. J. Exp. Med. 2000, 192, 1027-1034. [CrossRef]

50. Yamazaki, T.; Akiba, H.; Iwai, H.; Matsuda, H.; Aoki, M.; Tanno, Y.; Shin, T.; Tsuchiya, H.; Pardoll, D.; Okumura, K.; et al. Expression of programmed death 1 ligands by murine T cells and APC. J. Immunol. 2002, 169, 5538-5545. [CrossRef]

51. D'Arrigo, P.; Tufano, M.; Rea, A.; Vigorito, V.; Novizio, N.; Russo, S.; Romano, M.; Romano, S. Manipulation of the immune system for cancer defeat: A focus on the T cell inhibitory checkpoint molecules. Curr. Med. Chem. 2018. [CrossRef] [PubMed]

52. De Sousa Linhares, A.; Leitner, J.; Grabmeier-Pfistershammer, K.; Steinberger, P. Not All Immune Checkpoints Are Created Equal. Front. Immunol. 2018, 9, 1909. [CrossRef] [PubMed]

53. Wolchok, J.; Kluger, H.; Callahan, M.; Postow, M.; Rizvi, N.; Lesokhin, A.; Segal, N.; Ariyan, C.; Gordon, R.; Reed, K.; et al. Nivolumab plus ipilimumab in advanced melanoma. N. Engl. J. Med. 2013, 369, 122-133. [CrossRef] [PubMed]

54. Carlino, M.; Long, G.; Schadendorf, D.; Robert, C.; Ribas, A.; Richtig, E.; Nyakas, M.; Caglevic, C.; Tarhini, A.; Blank, C.; et al. Outcomes by line of therapy and programmed death ligand 1 expression in patients with advanced melanoma treated with pembrolizumab or ipilimumab in KEYNOTE-006: A randomised clinical trial. Eur. J. Cancer 2018, 101, 236-243. [CrossRef] 
55. Daud, A.; Wolchok, J.; Robert, C.; Hwu, W.; Weber, J.; Ribas, A.; Hodi, F.; Joshua, A.; Kefford, R.; Hersey, P.; et al. Programmed Death-Ligand 1 Expression and Response to the Anti-Programmed Death 1 Antibody Pembrolizumab in Melanoma. J. Clin. Oncol. 2016, 34, 4012-4109. [CrossRef]

56. Festino, L.; Botti, G.; Lorigan, P.; Masucci, G.; Hipp, J.; Horak, C.; Melero, I.; Ascierto, P. Cancer Treatment with Anti-PD-1/PD-L1 Agents: Is PD-L1 Expression a Biomarker for Patient Selection? Drugs 2016, 76, 925-945. [CrossRef]

57. Hodi, F.; Chiarion-Sileni, V.; Gonzalez, R.; Grob, J.; Rutkowski, P.; Cowey, C.; Lao, C.; Schadendorf, D.; Wagstaff, J.; Dummer, R.; et al. Nivolumab plus ipilimumab or nivolumab alone versus ipilimumab alone in advanced melanoma (CheckMate 067): 4-year outcomes of a multicentre, randomised, phase 3 trial. Lancet Oncol. 2018, 19, 1480-1492. [CrossRef]

58. Conroy, J.; Pabla, S.; Nesline, M.; Glenn, S.; Papanicolau-Sengos, A.; Burgher, B.; Andreas, J.; Giamo, V.; Wang, Y.; Lenzo, F.; et al. Next generation sequencing of PD-L1 for predicting response to immune checkpoint inhibitors. J. Immunother. Cancer 2019, 7, 18. [CrossRef]

59. Robert, C.; Long, G.; Brady, B.; Dutriaux, C.; Maio, M.; Mortier, L.; Hassel, J.; Rutkowski, P.; McNeil, C.; Kalinka-Warzocha, E.; et al. Nivolumab in previously untreated melanoma without BRAF mutation. N. Engl. J. Med. 2015, 372, 320-330. [CrossRef]

60. Kambayashi, Y.; Fujimura, T.; Hidaka, T.; Aiba, S. Biomarkers for Predicting Efficacies of Anti-PD1 Antibodies. Front. Med. 2019, 6, 174. [CrossRef]

61. Franzen, A.; Vogt, T.; Müller, T.; Dietrich, J.; Schröck, A.; Golletz, C.; Brossart, P.; Bootz, F.; Landsberg, J.; Kristiansen, G.; et al. PD-L1 (CD274) and PD-L2 (PDCD1LG2) promoter methylation is associated with HPV infection and transcriptional repression in head and neck squamous cell carcinomas. Oncotarget 2017, 9, 641-650. [CrossRef] [PubMed]

62. Said, E.; Al-Reesi, I.; Al-Riyami, M.; Al-Naamani, K.; Al-Sinawi, S.; Al-Balushi, M.; Koh, C.; Al-Busaidi, J.; Idris, M.; Al-Jabri, A. A Potential Inhibitory Profile of Liver CD68+ Cells during HCV Infection as Observed by an Increased CD80 and PD-L1 but Not CD86 Expression. PLoS ONE 2016, 11, e0153191. [CrossRef] [PubMed]

63. Okuma, Y.; Hishima, T.; Kashima, J.; Homma, S. High PD-L1 expression indicates poor prognosis of HIV-infected patients with non-small cell lung cancer. Cancer Immunol. Immunother. 2018, 67, 495-505. [CrossRef] [PubMed]

64. Choschzick, M.; Gut, A.; Fink, D. PD-L1 receptor expression in vulvar carcinomas is HPV-independent. Virchows Arch. 2018, 473, 513-516. [CrossRef] [PubMed]

65. Green, M.; Rodig, S.; Juszczynski, P.; Ouyang, J.; Sinha, P.; O’Donnell, E.; Neuberg, D.; Shipp, M. Constitutive AP-1 activity and EBV infection induce PD-L1 in Hodgkin lymphomas and posttransplant lymphoproliferative disorders: Implications for targeted therapy. Clin. Cancer Res. 2012, 18, 1611-1618. [CrossRef] [PubMed]

66. Severa, M.; Giacomini, E.; Gafa, V.; Anastasiadou, E.; Rizzo, F.; Corazzari, M.; Romagnoli, A.; Trivedi, P.; Fimia, G.; Coccia, E. EBV stimulates TLR- and autophagy-dependent pathways and impairs maturation in plasmacytoid dendritic cells: Implications for viral immune escape. Eur. J. Immunol. 2013, 43, 147-158. [CrossRef] [PubMed]

67. Fang, W.; Zhang, J.; Hong, S.; Zhan, J.; Chen, N.; Qin, T.; Tang, Y.; Zhang, Y.; Kang, S.; Zhou, T.; et al. EBV-driven LMP1 and IFN- $\gamma$ up-regulate PD-L1 in nasopharyngeal carcinoma: Implications for oncotargeted therapy. Oncotarget 2014, 5, 12189-12202. [CrossRef]

68. Outh-Gauer, S.; Alt, M.; Le Tourneau, C.; Augustin, J.; Broudin, C.; Gasne, C.; Denize, T.; Mirghani, H.; Fabre, E.; Scotte, F.; et al. Immunotherapy in head and neck cancers: A new challenge for immunologists, pathologists and clinicians. Cancer Treat. Rev. 2018, 665, 54-64. [CrossRef]

69. Sun, C.; Lan, P.; Han, Q.; Huang, M.; Zhang, Z.; Xu, G.; Song, J.; Wang, J.; Wei, H.; Zhang, J.; et al. Oncofetal gene SALL4 reactivation by hepatitis B virus counteracts miR-200c in PD-L1-induced T cell exhaustion. Nat. Commun. 2018, 9, 1241. [CrossRef]

70. Balsitis, S.; Gali, V.; Mason, P.; Chaniewski, S.; Levine, S.; Wichroski, M.; Feulner, M.; Song, Y.; Granaldi, K.; Loy, J.; et al. Safety and efficacy of anti-PD-L1 therapy in the woodchuck model of HBV infection. PLoS ONE 2018, 13, e0190058. [CrossRef]

71. Park, C.; Cho, J.; Lee, J.; Kang, S.; An, J.; Choi, M.; Lee, J.; Sohn, T.; Bae, J.; Kim, S.; et al. Host immune response index in gastric cancer identified by comprehensive analyses of tumor immunity. Oncoimmunology 2017, 6, e1356150. [CrossRef] [PubMed] 
72. Fouad, H.; Raziky, M.; Aziz, R.; Sabry, D.; Aziz, G.; Ewais, M.; Sayed, A. Dendritic cell co-stimulatory and co-inhibitory markers in chronic HCV: An Egyptian study. World J. Gastroenterol. 2013, 19, 7711-7718. [CrossRef] [PubMed]

73. Choi, Y.; Jin, N.; Kelly, F.; Sakthivel, S.; Yu, T. Elevation of Alanine Aminotransferase Activity Occurs after Activation of the Cell-Death Signaling Initiated by Pattern-Recognition Receptors but before Activation of Cytolytic Effectors in NK or CD8+ T Cells in the Liver During Acute HCV Infection. PLoS ONE 2016, 11, e0165533. [CrossRef] [PubMed]

74. Ojiro, K.; Qu, X.; Cho, H.; Park, J.; Vuidepot, A.; Lissin, N.; Molloy, P.; Bennett, A.; Jakobsen, B.; Kaplan, D.; et al. Modulation of Hepatitis C Virus-Specific CD8 Effector T-Cell Function with Antiviral Effect in Infectious Hepatitis C Virus Coculture Model. J. Virol. 2017, 91, e02129-16. [CrossRef]

75. Abdellatif, H.; Shiha, G. PD-L1 Expression on Circulating CD34 + Hematopoietic Stem Cells Closely Correlated with T-cell Apoptosis in Chronic Hepatitis C Infected Patients. Int. J. Stem. Cells 2018, 11, 78-86. [CrossRef]

76. Domblides, C.; Antoine, M.; Hamard, C.; Rabbe, N.; Rodenas, A.; Vieira, T.; Crequit, P.; Cadranel, J.; Lavolé, A.; Wislez, M. Nonsmall cell lung cancer from HIV-infected patients expressed programmed cell death-ligand 1 with marked inflammatory infiltrates. AIDS 2018, 32, 461-468.

77. Muthumani, K.; Shedlock, D.; Choo, D.; Fagone, P.; Kawalekar, O.; Goodman, J.; Bian, C.; Ramanathan, A.; Atman, P.; Tebas, P.; et al. HIV-mediated phosphatidylinositol 3-kinase/serine-threonine kinase activation in APCs leads to programmed death-1 ligand upregulation and suppression of HIV-specific CD8 T cells. J. Immunol. 2011, 187, 29322-29343. [CrossRef]

78. Meier, A.; Bagchi, A.; Sidhu, H.; Alter, G.; Suscovich, T.; Kavanagh, D.; Streeck, H.; Brockman, M.; LeGall, S.; Hellman, J.; et al. Upregulation of PD-L1 on monocytes and dendritic cells by HIV-1 derived TLR ligands. AIDS 2008, 22, 655-658. [CrossRef]

79. Planès, R.; BenMohamed, L.; Leghmari, K.; Delobel, P.; Izopet, J.; Bahraoui, E. HIV-1 Tat protein induces PD-L1 (B7-H1) expression on dendritic cells through tumor necrosis factor alpha- and toll-like receptor 4-mediated mechanisms. J. Virol. 2014, 88, 6672-6689. [CrossRef]

80. Hong, A.; Vilain, R.; Romanes, S.; Yang, J.; Smith, E.; Jones, D.; Scolyer, R.; Lee, C.; Zhang, M.; Rose, B. PD-L1 expression in tonsillar cancer is associated with human papillomavirus positivity and improved survival: Implications for anti-PD1 clinical trials. Oncotarget 2016, 7, 77010-77020. [CrossRef]

81. Lyford-Pike, S.; Peng, S.; Young, G.; Taube, J.; Westra, W.; Akpeng, B.; Bruno, T.; Richmon, J.; Wang, H.; Bishop, J.; et al. Evidence for a role of the PD-1:PD-L1 pathway in immune resistance of HPV-associated head and neck squamous cell carcinoma. Cancer Res. 2013, 73, 1733-1741. [CrossRef] [PubMed]

82. Yang, W.; Song, Y.; Lu, Y.; Sun, J.; Wang, H. Increased expression of programmed death (PD)-1 and its ligand PD-L1 correlates with impaired cell-mediated immunity in high-risk human papillomavirus-related cervical intraepithelial neoplasia. Immunology 2013, 139, 513-522. [CrossRef] [PubMed]

83. Lin, P.; Cheng, Y.; Wu, D.; Huang, Y.; Lin, H.; Chen, C.; Lee, H. A combination of anti-PD-L1 mAb plus Lm-LLO-E6 vaccine efficiently suppresses tumor growth and metastasis in HPV-infected cancers. Cancer Med. 2017, 6, 2052-2062. [CrossRef] [PubMed]

84. Lipson, E.; Vincent, J.; Loyo, M.; Kagohara, L.; Luber, B.; Wang, H.; Xu, H.; Nayar, S.; Wang, T.; Sidransky, D.; et al. PD-L1 expression in the Merkel cell carcinoma microenvironment: Association with inflammation, Merkel cell polyomavirus and overall survival. Cancer Immunol. Res. 2013, 1, 54-63. [CrossRef] [PubMed]

85. Ikebuchi, R.; Konnai, S.; Shirai, T.; Sunden, Y.; Murata, S.; Onuma, M.; Ohashi, K. Increase of cells expressing PD-L1 in bovine leukemia virus infection and enhancement of anti-viral immune responses in vitro via PD-L1 blockade. Vet. Res. 2011, 42, 103. [CrossRef]

86. Host, K.; Jacobs, S.; West, J.; Zhang, Z.; Costantini, L.; Stopford, C.; Dittmer, D.; Damania, B. Kaposi's Sarcoma-Associated Herpesvirus Increases PD-L1 and Proinflammatory Cytokine Expression in Human Monocytes. MBio 2017, 8, e00917-17. [CrossRef]

87. Good-Jacobson, K.; Szumilas, C.; Chen, L.; Sharpe, A.; Tomayko, M.; Shlomchik, M. PD-1 regulates germinal center B cell survival and the formation and affinity of long-lived plasma cells. Nat. Immunol. 2010, 11, 535-542. [CrossRef]

88. Lino, A.; Dang, V.; Lampropoulou, V.; Welle, A.; Joedicke, J.; Pohar, J.; Simon, Q.; Thalmensi, J.; Baures, A.; Flühler, V;; et al. LAG-3 Inhibitory Receptor Expression Identifies Immunosuppressive Natural Regulatory Plasma Cells. Immunity 2018, 49, 1. [CrossRef] 
89. Cain, D.; Cidlowski, J. Immune regulation by glucocorticoids. Nat. Rev. Immunol. 2017, 17, $233-247$. [CrossRef]

90. Franco, L.; Gadkari, M.; Howe, K.; Sun, J.; Kardava, L.; Kumar, P.; Kumari, S.; Hu, Z.; Fraser, I.; Moir, S.; et al. Immune regulation by glucocorticoids can be linked to cell type-dependent transcriptional responses. J. Exp. Med. 2019, 216, 384-406. [CrossRef]

91. Obradović, M.; Hamelin, B.; Manevski, N.; Couto, J.; Sethi, A.; Coissieux, M.; Münst, S.; Okamoto, R.; Kohler, H.; Schmidt, A.; et al. Glucocorticoids promote breast cancer metastasis. Nature 2019, 567, 540-544. [CrossRef] [PubMed]

92. Torino, F.; Barnabei, A.; Paragliola, R.; Marchetti, P.; Salvatori, R.; Corsello, S. Endocrine side-effects of anti-cancer drugs: mAbs and pituitary dysfunction: Clinical evidence and pathogenic hypotheses. Eur. J. Endocrinol. 2013, 169, R153-R164. [CrossRef] [PubMed]

93. Sznol, M.; Postow, M.; Davies, M.; Pavlick, A.; Plimack, E.; Shaheen, M.; Veloski, C.; Robert, C. Endocrine-related adverse events associated with immune checkpoint blockade and expert insights on their management. Cancer Treat. Rev. 2017, 58, 70-76. [CrossRef] [PubMed]

94. Kametani, Y.; Miyamoto, A.; Seki, T.; Ito, R.; Habu, S.; Tokuda, Y. The significance of humanized mouse models for the evaluation of the humoral immune response against cancer vaccines. Pers. Med. Univ. 2018, 7, 13-18. [CrossRef]

95. Chen, Q.; Wang, J.; Liu, W.; Zhao, Y. Cancer Immunotherapies and Humanized Mouse Drug Testing Platforms. Transl. Oncol. 2019, 12, 987-995. [CrossRef]

96. Ukai, H.; Sumiyama, K.; Ueda, H. Next-generation human genetics for organism-level systems biology. Curr. Opin. Biotechnol. 2019, 58, 137-145. [CrossRef]

97. Ito, M.; Kobayashi, K.; Nakahata, T. NOD/Shi-scid IL2rgamma(null) (NOG) mice more appropriate for humanized mouse models. Curr. Top. Microbiol. Immunol. 2008, 324, 53-76.

98. Yajima, M.I.K. Nakagawa A, Watanabe S, Terashima K, Nakamura H, Ito M, Shimizu N, Honda M, Yamamoto N, Fujiwara S, A new humanized mouse model of Epstein-Barr virus infection that reproduces persistent infection, lymphoproliferative disorder, and cell-mediated and humoral immune responses. J. Infect. Dis. 2008, 198, 673-682.

99. Brehm, M.; Wiles, M.; Greiner, D.; Shultz, L. Generation of improved humanized mouse models for human infectious diseases. J. Immunol. Methods 2014, 410, 3-17. [CrossRef]

100. Hasgur, S.; Aryee, K.; Shultz, L.; Greiner, D.; Brehm, M. Generation of Immunodeficient Mice Bearing Human Immune Systems by the Engraftment of Hematopoietic Stem Cells. Methods Mol. Biol. 2016, 1438, 67-78.

101. Willinger, T.; Rongvaux, A.; Takizawa, H.; Yancopoulos, G.; Valenzuela, D.; Murphy, A.; Auerbach, W.; Eynon, E.; Stevens, S.; Manz, M.; et al. Human IL-3/GM-CSF knock-in mice support human alveolar macrophage development and human immune responses in the lung. Proc. Natl. Acad. Sci. USA 2011, 108, 2390-2395. [CrossRef] [PubMed]

102. Singh, M.; Singh, P.; Gaudray, G.; Musumeci, L.; Thielen, C.; Vaira, D.; Vandergeeten, C.; Delacroix, L.; Van Gulck, E.; Vanham, G.; et al. An improved protocol for efficient engraftment in NOD/LTSZ-SCIDIL-2R $\gamma$ null mice allows HIV replication and development of anti-HIV immune responses. PLoS ONE 2012, 7, e38491. [CrossRef] [PubMed]

103. Ito, R.; Takahashi, T.; Katano, I.; Kawai, K.; Kamisako, T.; Ogura, T.; Ida-Tanaka, M.; Suemizu, H.; Nunomura, S.; Ra, C.; et al. Establishment of a human allergy model using human IL-3/GM-CSF-transgenic NOG mice. J. Immunol. 2013, 191, 2890-2899. [CrossRef] [PubMed]

104. Goyama, S.; Wunderlich, M.; Mulloy, J. Xenograft models for normal and malignant stem cells. Blood 2015, 125, 2630-2640. [CrossRef]

105. Villaudy, J.; Schotte, R.; Legrand, N.; Spits, H. Critical assessment of human antibody generation in humanized mouse models. J. Immunol. Methods 2014, 410, 18-27. [CrossRef]

106. Ito, M.; Hiramatsu, H.; Kobayashi, K.; Suzue, K.; Kawahata, M.; Hioki, K.; Ueyama, Y.; Koyanagi, Y.; Sugamura, K.; Tsuji, K.; et al. NOD/SCID/gamma(c)(null) mouse: An excellent recipient mouse model for engagement of human cells. Blood 2002, 100, 3175-3182. [CrossRef]

107. Shultz, L.; Ishikawa, F.; Greiner, D. Humanized mice in translational biomedical research. Nat. Rev. Immunol. 2007, 7, 118-130. [CrossRef] 
108. Shultz, L.D.; Lang, P.A.; Christianson, S.W.; Gott, B.; Lyons, B.; Umeda, S.; Leiter, E.; Hesselton, R.; Wagar, E.J.; Leif, J.H.; et al. NOD/LtSz-Rag1null mice: An immunodeficient and radioresistant model for engraftment of human hematolymphoid cells, HIV infection, and adoptive transfer of NOD mouse diabetogenic T cells. J. Immunol. 2000, 164, 2496-2507. [CrossRef]

109. Matumura, T.; Kametani, Y.; Ando, K.; Hirano, Y.; Katano, I.; Ito, R.; Shiina, M.; Tsukmoto, H.; Saito, Y.; Tokuda, Y.; et al. Functional CD5+ B cells develop predominantly in the spleen of NOD/SCID/gc null (NOG) mice transplanted either with human umbilical cord blood, bone marrow, or mobilized peripheral blood CD34+ cells. Exp. Hematol. 2003, 31, 789-797. [CrossRef]

110. Watanabe, S.; Terashima, K.; Ohta, S.; Horibata, S.; Yajima, M.; Shiozawa, Y.; Dewan, M.; Yu, Z.; Ito, M.; Morio, T.; et al. Hematopoietic stem cell-engrafted NOD/SCID/IL2Rgamma null mice develop human lymphoid systems and induce long-lasting HIV-1 infection with specific humoral immune responses. Blood 2007, 109, 212-218. [CrossRef]

111. Lepus, C.; Gibson, T.; Gerber, S.; Kawikova, I.; Szczepanik, M.; Hossain, J.; Ablamunits, V.; Kirkiles-Smith, N.; Herold, K.; Donis, R.; et al. Comparison of human fetal liver, umbilical cord blood, and adult blood hematopoietic stem cell engraftment in NOD-scid/gammac-/-, Balb/c-Rag1-/-gammac-/-, and C.B-17-scid/bg immunodeficient mice. Hum. Immunol. 2009, 70, 790-802. [CrossRef] [PubMed]

112. Watanabe, Y.; Takahashi, T.; Okajima, A.; Shiokawa, M.; Ishii, N.; Katano, I.; Ito, R.; Ito, M.; Minegishi, M.; Minegishi, N.; et al. The analysis of the functions of human B and T cells in humanized NOD/shi-scid/gammac(null) (NOG) mice (hu-HSC NOG mice). Int Immunol. 2009, 21, 843-858. [CrossRef] [PubMed]

113. Biswas, S.; Chan, G.H.; Sarkis, P.; Fikrig, E.; Zhu, Q.; Marasco, W. Humoral immune responses in humanized BLT mice immunized with West Nile virus and HIV-1 envelope proteins are largely mediated via human CD5+ B cells. Immunology 2011, 134, 419-433. [CrossRef] [PubMed]

114. Kametani, Y.; Shiina, M.; Katano, I.; Ito, R.; Ando, K.; Toyama, K.; Tsukamoto, H.; Matsumura, T.; Saito, Y.; Ishikawa, D.; et al. Development of human-human hybridoma from anti-Her-2 peptide-producing B cells in immunized NOG mouse. Exp. Hematol. 2006, 34, 1240-1248. [CrossRef]

115. Kametani, Y.; Shimada, S.; Mori, S.; Kojima, M.; Ohshima, S.; Kitaura, K.; Matsutani, T.; Okada, Y.; Yahata, T.; Ito, R.; et al. Antibody-secreting plasma cells with unique CD5+IgG+CD21lo phenotype developed in humanized NOG mice. Clin. Res. Trials 2016, 2, 164-173. [CrossRef]

116. Kametani, Y.; Katano, I.; Miyamoto, A.; Kikuchi, Y.; Ito, R.; Muguruma, Y.; Tsuda, B.; Habu, S.; Tokuda, Y.; Ando, K.; et al. NOG-hIL-4-Tg, a new humanized mouse model for producing tumor antigen-specific IgG antibody by peptide vaccination. PLoS ONE 2017, 12, e0179239. [CrossRef]

117. McCune, J. Development and applications of the SCID-hu mouse model. Semin. Immunol. 1996, 8, 187-196. [CrossRef]

118. Aaberge, I.; Michaelsen, T.; Rolstad, A.; Groeng, E.; Solberg, P.; Løvik, M. SCID-Hu mice immunized with a pneumococcal vaccine produce specific human antibodies and show increased resistance to infection. Infect. Immunol. 1992, 60, 4146-4153.

119. Suzuki, M.; Takahashi, T.; Katano, I.; Ito, R.; Ito, M.; Harigae, H.; Ishii, N.; Sugamura, K. Induction of human humoral immune responses in a novel HLA-DR-expressing transgenic NOD/Shi-scid/ $\gamma$ cnull mouse. Int. Immunol. 2012, 24, 243-252. [CrossRef]

120. Huang, J.; Li, X.; Coelho-dos-Reis, J.; Zhang, M.; Mitchell, R.; Nogueira, R.; Tsao, T.; Noe, A.; Ayala, R.; Sahi, V.; et al. Human immune system mice immunized with Plasmodium falciparum circumsporozoite protein induce protective human humoral immunity against malaria. J. Immunol. Methods 2015, 427, 42-50. [CrossRef]

121. Williams, S.; Umemoto, T.; Kida, H.; Repasky, E.; Bankert, R. Engraftment of human peripheral blood leukocytes into severe combined immunodeficient mice results in the long term and dynamic production of human xenoreactive antibodies. J. Immunol. 1992, 149, 2830-2836. [PubMed]

122. Aono, S.; Tatsumi, T.; Yoshioka, T.; Tawara, S.; Nishio, A.; Onishi, Y.; Fukutomi, K.; Nakabori, T.; Kodama, T.; Shigekawa, M.; et al. Immunological responses against hepatitis B virus in human peripheral blood mononuclear cell-engrafted mice. Biochem. Biophys Res. Commun. 2018, 503, 1457-1464. [CrossRef] [PubMed]

123. McCune, J.; Namikawa, R.; Kaneshima, H.; Shultz, L.; Lieberman, M.; Weissman, I. The SCID-hu mouse: Murine model for the analysis of human hematolymphoid differentiaiton and function. Schience 1988, 241, 1632-1639. [CrossRef] [PubMed] 
124. Jaiswal, S.; Smith, K.; Ramirez, A.; Woda, M.; Pazoles, P.; Shultz, L.; Greiner, D.; Brehm, M.; Mathew, A. Dengue virus infection induces broadly cross-reactive human IgM antibodies that recognize intact virions in humanized BLT-NSG mice. Exp. Biol. Med. 2015, 240, 67-78. [CrossRef] [PubMed]

125. Jangalwe, S.; Shultz, L.; Mathew, A.; MA, B. Improved B cell development in humanized NOD-scid IL2R $\gamma^{\text {null }}$ mice transgenically expressing human stem cell factor, granulocyte-macrophage colony-stimulating factor and interleukin-3. Immunol. Inflamm. Dis. 2016, 4, 427-440. [CrossRef]

126. Schmitt, K.; Charlins, P.; Veselinovic, M.; Kinner-Bibeau, L.; Hu, S.; Curlin, J.; Remling-Mulder, L.; Olson, K.; Aboellail, T.; Akkina, R. Zika viral infection and neutralizing human antibody response in a BLT humanized mouse model. Virology 2018, 515, 235-242. [CrossRef]

127. Gawron, M.; Duval, M.; Carbone, C.; Jaiswal, S.; Wallace, A.; Martin, J.C.; Dauphin, A.; Brehm, M.; Greiner, D.; Shultz, L.; et al. Human Anti-HIV-1 gp120 Monoclonal Antibodies with Neutralizing Activity Cloned from Humanized Mice Infected with HIV-1. J. Immunol. 2019, 202, 799-804. [CrossRef]

128. Srivastava, R.; Khan, A.; Spencer, D.; Vahed, H.; Lopes, P.; Thai, N.; Wang, C.; Pham, T.; Huang, J.; Scarfone, V.; et al. HLA-A02:01-restricted epitopes identified from the herpes simplex virus tegument protein VP11/12 preferentially recall polyfunctional effector memory CD8+ T cells from seropositive asymptomatic individuals and protect humanized HLA-A*02:01 transgenic mice against ocular herpes. J. Immunol. 2015, 194, 2232-2248.

129. Najima, Y.; Tomizawa-Murasawa, M.; Saito, Y.; Watanabe, T.; Ono, R.; Ochi, T.; Suzuki, N.; Fujiwara, H.; Ohara, O.; Shultz, L.; et al. Induction of WT1-specific human CD8+ T cells from human HSCs in HLA class I Tg NOD/SCID/IL2rgKO mice. Blood 2016, 127, 722-734. [CrossRef]

130. Jespersen, H.; Lindberg, M.; Donia, M.; Söderberg, E.; Andersen, R.; Keller, U.; Ny, L.; Svane, I.; Nilsson, L.; Nilsson, J. Clinical responses to adoptive T-cell transfer can be modeled in an autologous immune-humanized mouse model. Nat. Commun. 2017, 8, 707. [CrossRef]

131. Meehan, T.; Conte, N.; Goldstein, T.; Inghirami, G.; Murakami, M.; Brabetz, S.; Gu, Z.; Wiser, J.; Dunn, P.; Begley, D.; et al. PDX-MI: Minimal Information for Patient-Derived Tumor Xenograft Models. Cancer Res. 2017, 77, e62-e66. [CrossRef] [PubMed]

132. Okada, S.; Vaeteewoottacharn, K.; Kariya, R. Application of Highly Immunocompromised Mice for the Establishment of Patient-Derived Xenograft (PDX) Models. Cells 2019, 8, 889. [CrossRef] [PubMed]

133. Shi, J.; Li, Y.; Jia, R.; Fan, X. The fidelity of cancer cells in PDX models: Characteristics, mechanism and clinical significance. Int. J. Cancer 2019. [CrossRef] [PubMed]

134. Marangoni, E.; Poupon, M. Patient-derived tumour xenografts as models for breast cancer drug development. Curr. Opin. Oncol. 2014, 26, 556-561. [CrossRef]

135. Ashizawa, T.; Iizuka, A.; Nonomura, C.; Kondou, R.; Maeda, C.; Miyata, H.; Sugino, T.; Mitsuya, K.; Hayashi, N.; Nakasu, Y.; et al. Antitumor Effect of Programmed Death-1 (PD-1) Blockade in Humanized the NOG-MHC Double Knockout Mouse. Clin. Cancer Res. 2017, 23, 149-158. [CrossRef]

136. Joo, S.Y.; Chung, Y.S.; Choi, B.; Kim, M.; Kim, J.H.; Jun, T.G.; Chang, J.; Sprent, J.; Surh, C.D.; Joh, J.W.; et al. Systemic human $\mathrm{T}$ cell developmental processes in humanized mice cotransplanted with human fetal thymus/liver tissue and hematopoietic stem cells. Transplantation 2012, 94, 1095-1102. [CrossRef]

137. Ito, R.; Katano, I.; Kawai, K.; Yagoto, M.; Takahashi, T.; Ka, Y.; Ogura, T.; Takahashi, R.; Ito, M. A Novel Xenogeneic Graft-Versus-Host Disease Model for Investigating the Pathological Role of Human CD4+ or CD8+ T Cells Using Immunodeficient NOG Mice. Am. J. Transplant. 2017, 17, 1216-1228. [CrossRef]

138. Seki, T.; Miyamoto, A.; Ohshima, S.; Ohno, Y.; Yasuda, A.; Tokuda, Y.; Ando, K.; Kametani, Y. Expression of glucocorticoid receptor shows negative correlation with human B-cell engraftment in PBMC-transplanted NOGhIL-4-Tg mice. Biosci. Trends 2018, 12, 247-256. [CrossRef]

(C) 2019 by the authors. Licensee MDPI, Basel, Switzerland. This article is an open access article distributed under the terms and conditions of the Creative Commons Attribution (CC BY) license (http://creativecommons.org/licenses/by/4.0/). 